\title{
Tofu Product Branding for Culinary Tourism of Sumedang, Indonesia
}

\author{
Dasrun Hidayat ${ }^{1, \text { a) }}$ Hanny Hafiar ${ }^{3)}$ Anisti $^{2)}$ \\ ${ }^{1}$ Universitas ARS, Bandung, Indonesia \\ ${ }^{2}$ Universitas Padjadjaran, Indonesia. \\ ${ }^{3}$ Universitas Bina Sarana Informatika, Jakarta, Indonesia. \\ a) author correspondence : dasrun.dhy78@gmail.com
}

_. DOI: https://doi.org/10.18196/jkm.112022

Article Info

Article history:

Received 04 Jul 2019

Revised 12 Oct 2019

Accepted 13 Nov 2019

\begin{abstract}
Measuring standards for the management of tofu products as culinary tourism can contribute to the branding of the city of Sumedang, Indonesia. With the challenges in the technology era 4.0 the culinary industry, including Sumedang, is demanded to do branding through digital technology. This is the background of the importance of this study. The research design uses the ethnographic study of public relations with a qualitative approach. Data collection involved 4 producers and 4 consumers through interview and observation techniques. This research found differentiation as a strategy for managing tofu products. The differentiation strategy includes the use of digital promotional media in the form of websites and social media, which previously only used conventional media, such as banners. Differentiation can also be found in packaging using boxes made of woven bamboo. Another differentiation is in the variation of flavors by adding sambal kecap (chili soy sauce), sambal oncom (chili sauce mixed with a fermented caked product made of peanut press cake), sambal hejo (green chili sauce) in addition to its original accompaniment of the whole chilies. However, these changes do not change the tofu price of around 500 rupiahs per piece. Differentiation as an effort to build the branding of Sumedang city is what drives the local government to make tofu products as culinary tourism. This study offers a concept of culinary tourism as cultural tourism in Sumedang. The concept of this tourism has not been much researched, although culinary culture is one of the intellectual properties that must be developed. Product development through product differentiation and convergence of Internet-based media is a product communication strategy effort for managing Sumedang Tofu products.
\end{abstract}

Keywords: City Branding; Culinary Culture; Differentiation; Product Brand;

ABSTRAK

Mengukur standar pengelolaan produk tahu sebagai wisata kuliner dapat berkontribusi terhadap branding kota Sumedang, Indonesia. Dengan adanya tantangan di era teknologi 4.0 dimana industri kuliner, tidak terkecuali tahu Sumedang, dituntut untuk melakukan branding melalui teknologi digital. Hal ini yang menjadi latar belakang pentingnya penelitian ini dilakukan. Desain penelitian menggunakan studi etnografi public relations dengan pendekatan kualitatif. Pengumpulan data melibatkan 4 produsen dan 4 konsumen melalui teknik wawancara dan observasi. Penelitian ini menemukan diferensiasi sebagai strategi dalam mengelola produk tahu. Strategi diferensiasi meliputi penggunaan media promosi digital berupa situs web dan media sosial, yang sebelumnya hanya menggunakan media konvensional, seperti spanduk. Diferensiasi juga terdapat pada pengemasan dengan menggunakan kotak terbuat dari anyaman bambu. Diferensiasi yang lainnya adalah variasi rasa dengan menambahkan sambel kecap, sambel hejo, atau sambel oncom disamping bumbu original 
berupa butiran cabe. Namun perubahan-perubahan tersebut tidak merubah harga yaitu bertahan 500 rupiah perbuah. Diferensiasi sebagai upaya membangun branding kota Sumedang inilah yang mendorong pemerintah daerah untuk menjadikan produk tahu sebagai wisata kuliner. Penelitian ini menawarkan konsep wisata kuliner sebagai wisata budaya di kota Sumedang. Konsep wisata ini belum banyak diteliti, walaupun budaya kuliner merupakan salah satu kekayaan intelektual yang harus dikembangkan. Pengembangan produk melalui diferensiasi produk dan konvergensi media berbasis Internet merupakan upaya strategi komunikasi produk.

Keywords: Branding Kota; Budaya Kuliner; Diferensiasi; Merek Produk; Wisata

\section{INTRODUCTION}

The brand of a product reflects the concept and value offered to the public. The brand also represents the lifestyle and social status of a specific group of community. Kavaratzis (in Rezvanpour \& Bayat, 2017) identified the brand as to have three critical concepts related to identity, image, and communication. Hardyantoro \& Prianti (2012) mentioned that brand can be in forms of names, symbols, logos, and product graphics. Zenker et al. (2017) defined that brands can be tangible and intangible. Mila and Teresa (2009) described that the brand of a city should not only fit the concept of marketing, but it must also have characteristics. Barbero and Sandulli (in Hardyantoro \& Prianti, 2012) stated that brand identity should include an analysis of appearance, personality, humanity, and style. Murfianti (2012) stated that a brand is defined as a name, terminology, logo, symbol or design made to mark or identify products offered to consumers. Marconi (in Murfianti, 2012) contended that a brand is a combination of image, reputation, and performance. Rezvanpour \& Bayat (2017) cited a brand definition from the American Marketing Association (AMA), that brand is a name, term, design, symbol, or a combination of them. A brand is also a perceived impression in the minds of consumers of a product or service. According to Kapferer (in Rezvanpour \& Bayat, 2017) brand can be shaped or real and can also take the form of intangibles.

The brand that is meant in this article is a local product brand from Sumedang, tofu. Tofu products have been legendary all over the archipelago. Hazliansyah (2018) mentioned that since 1917, Sumedang Tofu has always been at the forefront of snack choice for the people in Indonesia. Tofu still maintained as a cultural icon of Sumedang culinary tourism. The popularity of Sumedang Tofu certainly is the evidence of success in the branding process of local culinary products of Sumedang and typically of Indonesia.

Branding is an effort to introduce the concept of established products, and branding is part of marketing activities (Zenker et al., 2017). Branding aims to provide information about brands product, develop brand awareness and creates a sense of closeness with consumers (Popa, Raba, \& Dumbravă, 2017). Branding can also be interpreted as an attempt to develop different association patterns to increase brand appeal and sales. Branding is an attempt to attract public interest. Branding of Sumedang Tofu is done continuously by the Sumedang community. These efforts are paying off because the Tofu brand, as a local culinary, is embedded within the hearts of society. It becomes an icon as well as the identity of Sumedang city. Ashworth (in Rezvanpour \& Bayat, 2017) described brand identity as part of the brand component. Brand identity is related to brand positioning and brand image. Sumedang Tofu product is another name or identity of the city and even the identity of the nation. Alifahmi (2012) mentioned that in building an image of a nation it is necessary to have country branding efforts that include personal branding, product branding, and corporate branding (Sholikhah, 2016). Similarly, Sumedang Tofu has become a product branding while famous creative tofu producers are part of personal branding.

Behind the big name of Sumedang Tofu, its history is only known to a few people. This food was firstly introduced in Sumedang in the 1917s when immigrants from China entered the East Priangan region, including the Sumedang city. This was also the origin of the name tofu, which was taken from the Chinese language, Doufu. For the people of Sumedang, tofu is part of cultural wealth. The Sumedang community has its way of managing tofu as a dependable menu while maintaining different tastes compared to other tofu in general. This strategy makes the brand and icon of 
Sumedang city. This icon has become popular following the Sumedang community's awareness of tofu as an intellectual property asset that must be developed. Through their efforts and creativity, the Sumedang community has succeeded in maintaining the reputation of Sumedang city as a creative city in developing a culinary business of tofu.

Sumedang community is known as a creative society; it is proven through the success of managing the existence of tofu as a typical culinary of Sumedang. Efforts have been made by presenting new tastes while maintaining its trademark or by conducting product differentiation. Karagiannis \& Pröll (2017) described differentiation as a strategy to maintain a product by adding or modifying the product. Product differentiation activities have a positive impact on consumer decisions to buy simultaneously (Gandhy \& Hairuddin, 2018). A research entitled Analysis of Promotion and Product Differentiation of Jukajo on Consumer Purchase Decision examines promotional and product differentiation variables. The results of this study show that there is an influence between promotional activities and product differentiation.

Similarly, the product management activities of Sumedang Tofu need to be studied further in terms of the interrelationship approach used in managing the products of Sumedang Tofu. This is what stimulates this study in the hope of knowing the approach used in managing local culinary products, which has successfully proven in maintaining the image and reputation of the product. The indicator of success can be measured from the public perception that the Tofu product is still the identity of the city or the city branding of Sumedang. This identity is also supported by the city tagline, namely Sumedang Tandang or the city that is ready to compete through its cultural and tourism potentials.

Based on the review of the literature and previous research, the authors were interested in deeply examine the differentiation and management of tofu products from Sumedang. The focus of this article is on the aspects of differentiating as a measure for city branding. Tofu product is identified as a universal food because the brand tofu is very familiar within the community. But from many tofu products, there are tofu products whose position is at the highest in the minds of consumers. Successful products take the hearts of consumers because these products stick strongly to become part of the brand positioning of so many brand identities of tofu that exist in Indonesia (Hazliansyah, 2018). Success in building a product brand certainly cannot be separated from the management procedures or product management. The process of product management is expected to help in building brand identity, brand positioning and brand image of the product. Product management is also expected to build city branding or the local brand of Sumedang as a city with the identity as a tofu producer.

\section{METHODS}

Epistemological research uses public relations ethnography method; a method that focuses on cultural studies with a public relations theory approach. Ethnographic studies of public relations focus on communication behavior to build relationships (Hidayat, Kuswarno \& Zubair, 2017). Public relations focus on planning, managing and maintaining a balance of relationships between the organization and the public (El-Kasim \& Idid, 2016). Ethnography public relations emphasizes the communication planning component in planning activities or cultural activities aimed at not only understanding communication behavior but also exploring patterns of relationships built on public support. The formula or unit of data analysis of public relations ethnographic studies is referred to as a component of public relations activities including Insight, Program Strategic, Program Implementation, Action and Reputation (IPPAR Model) (Hidayat, 2018). 


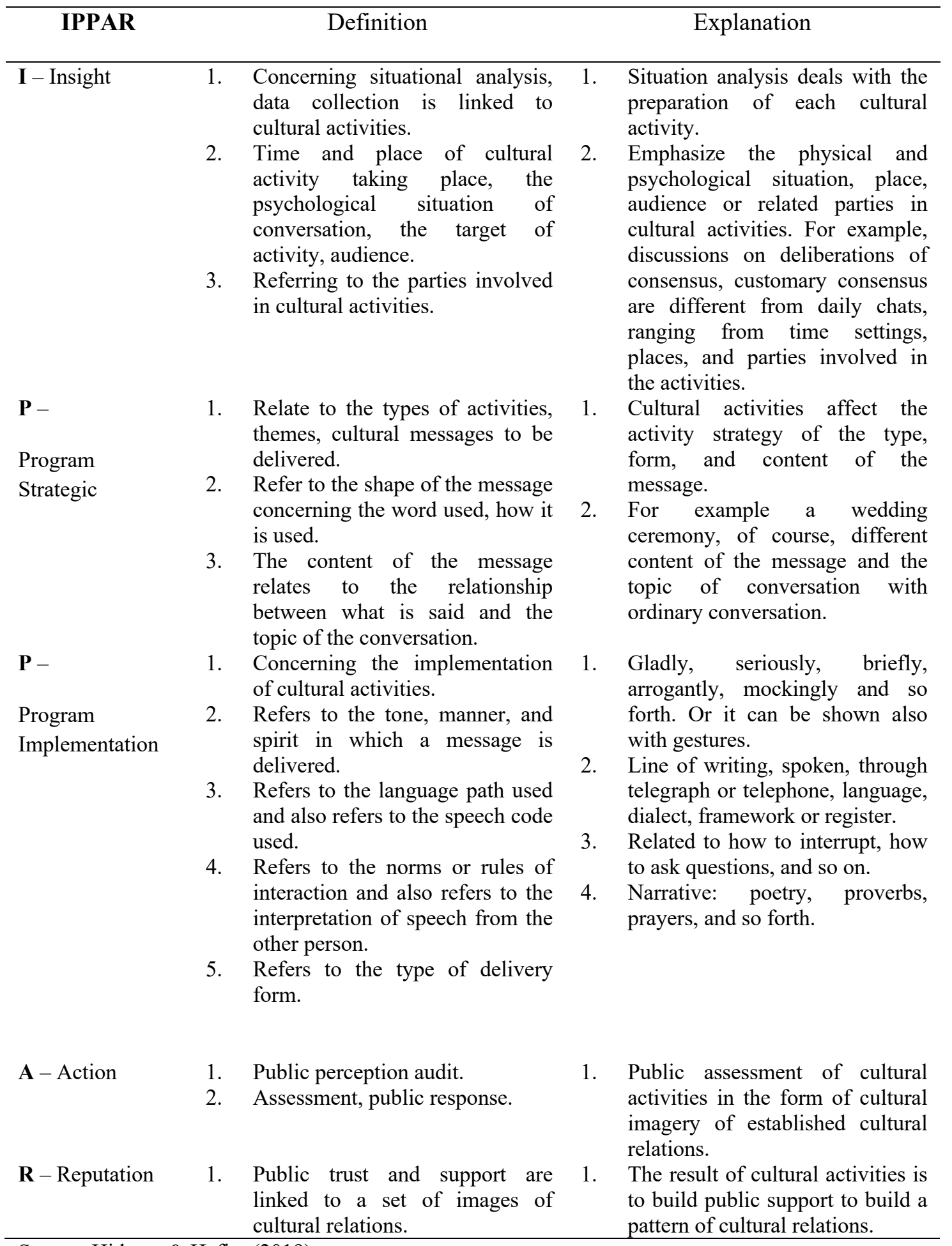

Source: Hidayat \& Hafiar (2019)

The relevance of public relations ethnography as a methodology in this research is on the focus of research problems, which are branding activities through differentiation brand products of Sumedang Tofu. Public awareness of the existence of the Tofu as intellectual property in the form of culinary culture encourages efforts always to manage and innovate by introducing a new brand of Sumedang Tofu. Brand or trademark starts from various names of Sumedang Tofu, the packaging, and how to serve it. This tofu product differentiation is based on the needs and competition of Tofu culinary as 
well as the belief of knowing it as a cultural icon that represents the local wisdom values of Sumedang community. According to Ulfa (in Hidayat, Kuswarno, Zubair \& Hafiar, 2017), local wisdom is a set of beliefs owned by the community and serves as a guideline in the activity. Similarly, the Sumedang community runs the Tofu culinary business hereditary. From generation to generation they keep Tofu culinary business as an economic identity.

The data of this study were collected through several stages following the needs of public relations ethnographic studies involving producers and consumers. The data collected included a review of documentation in the form of written historical documents which present in some media. The interview involved 4 producers and 4 consumers. The role of observation was the involvement of researchers in the research problem. Methodologically, qualitative research requires the researcher to be in the problem of being investigated not beyond the problem. Direct inter-subject involvement was expected to rediscover the related findings with the facts over the iconic branding characteristics of Sumedang Tofu. Branding activity aims at negotiating images that are contained in the charm of local culinary culture that has been known throughout the archipelago. Branding remains as an effort to maintain the reputation of Sumedang as a tourist city for tofu culinary of which was prepared to compete with other products.

\section{RESULT AND DISCUSSION}

As a culinary product, Sumedang Tofu is realized as a very famous tofu brand, and to maintain the brand, Sumedang Tofu producers are very aware of the importance of innovation and creativity. These are conducted to prevent consumers from being surfeited. Creativity is done through product management from the name to the taste. The power to be highlighted in the competition is the target public as consumers. Identify the market segments that can be served. This is in line with the theory of public relations that the initial stage in identifying the market segment is to set public as the target. The public consists of the internal and external public. Hidayat (2014) stated that public relations objectives are internal and external. Internal is the public objective of the organization, company, and community. The external public is outside consumers, stakeholders, and individuals outside the members of the community group. Internal goals or internal public and external objectives are called the external public. In the context of the discussion of the results of this study, what is meant by the public is the consumers who become the target of marketing activities of Sumedang Tofu products.

According to the interview participants, three things are noticed by the producers in managing the brand of Sumedang Tofu food products, namely packaging, taste, and price. The packaging is related to product appearance, the taste is an effort to notice the quality of consumer tastes, and the price is about the level of consumer purchasing power. These three main factors are consumer considerations that can be used as a basis for managing Sumedang Tofu products. Popa (Popa et al., 2017) mentioned that brand management is considered by consumers as an integral and valuable part of food products. This is an effort to distinguish it from other products offered in a competitive market. The action that can be taken in managing the product brand is making communication planning. Hidayat, Kuswarno \& Zubair (2017) said that planning includes Insight, Strategic Program, Implementation Program, Action, and Reputation (IPPAR Model). 


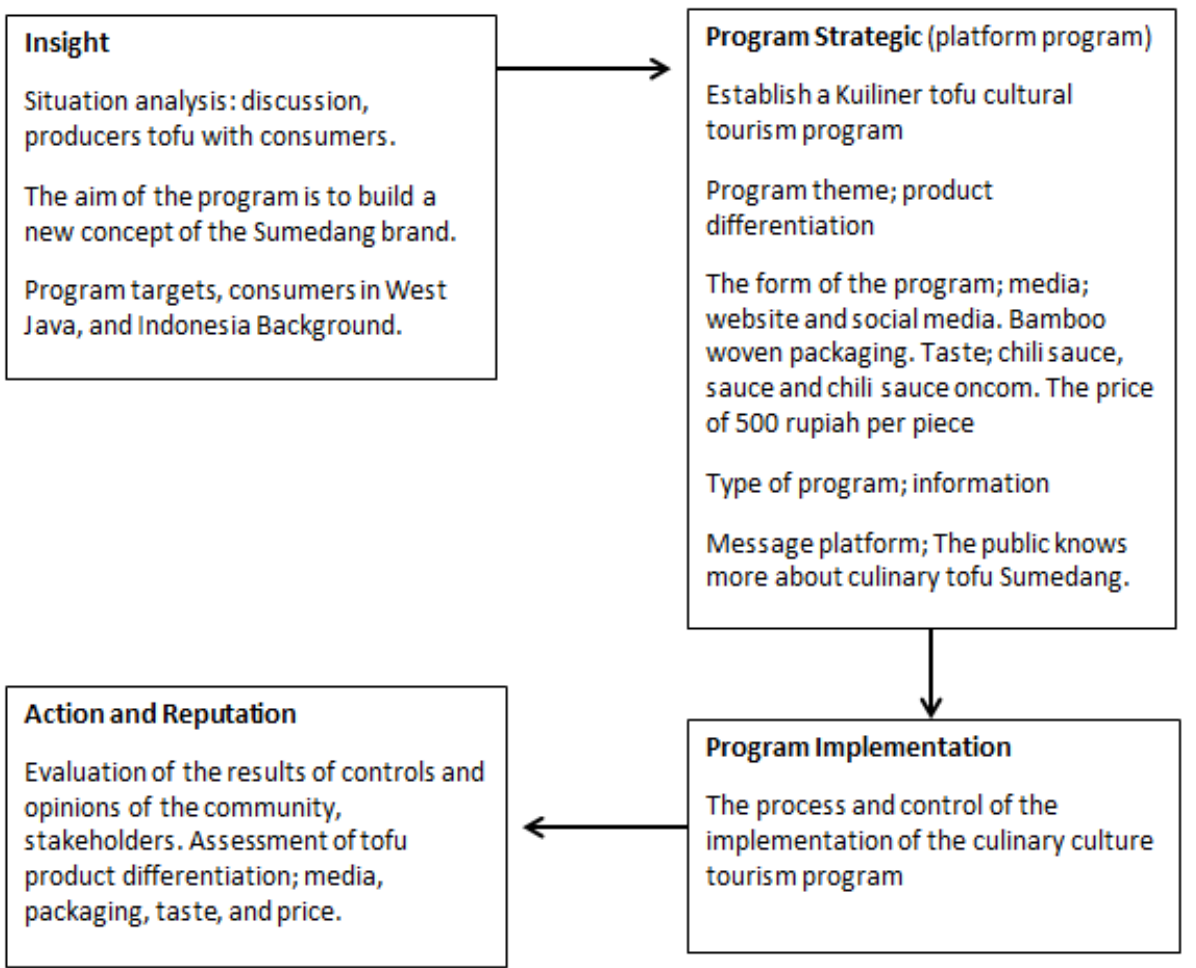

Figure1. The stages of planning the product differentiation program of Sumedang Tofu

\section{The insight stage.}

Insight is an early stage of communication planning that aims at identifying and defining the background activity or the manufacture of the product. Insight is also needed to reinforce the target consumers and target activities. Kotler (in Hidayat, 2012) stated that in determining the target market, many companies are implementing market targetting. In marketing, the target seller differentiates into major market segments and support segments. The product is usually developed or designed following the target or the target marketing made. According to Kotler, instead of wasting the marketing effort, it is a good idea to focus more on the buyers, identifying which is the thing they are most likely satisfied with. This is in line with the efforts made by the producers of Sumedang Tofu. At this stage, insight is done through data collection related to consumer desires. Insight is also called the stage of the situation analysis. Insight is the first step in the form of data mining as an effort to manage the brand, as mentioned by Wasesa (2011). In the context of the results of this study, Sumedang Tofu producers recognized that the data collection effort was done by asking directly to each consumer. Although the instrument has not been systematically made, however, a situation analysis or perceptions audit step is acknowledged as part of the management of Sumedang Tofu products.

Stages of insight on the Sumedang Tofu product differentiation program began with the situation analysis action. This stage aims at mapping the goals and objectives of the program. Analysis of the situation was carried out through interviews and discussions with consumers. The purpose of the program is to develop new concepts about the Sumedang Tofu brand through product differentiation. The program is aimed at people in West Java in particular and the people of Indonesia in general.

Furthermore, the existence of this differentiation is expected to make tofu products to be known by the world community through the website and social media. The use of digital-based media has not yet been optimized, although the tofu producers recognized this as a branding challenge in the industrial era 4.0. Within this competitive era, it is paramount to use technology 4.0 as a strategy to answer consumer needs. 


\section{The strategic program stage}

Communication planning in managing the Sumedang Tofu brand is also done by establishing a strategic program. Wilcox \& Cameron (in Wasesa, 2011) called it program planning. This stage determines the purpose, type of activities, objectives, message content, strategy and tactics. Kotler (in Hidayat, 2012) said that communication planning in business sciences aims at establishing three main business planning steps, including (1) packaging, (2) price, and (3) flavor. Some theories presented are relevant to the findings of these research results. Sumedang Tofu producers acknowledged that they always considered every new type of taste in Tofu products. The flavor is a variant of various chili sauce flavors which includes sambal kecap (chili soy sauce), sambal oncom (chili sauce mixed with a fermented caked product made of peanut press cake), sambal hejo (green chili sauce) and original flavor by serving some whole chilies as a companion of Tofu. The presence of various variants of sambal is a form of keeping the taste so that consumers do not get bored. Decision making on Tofu differentiation through a variety of sambal as a side dish for tofu looks simple, but no matter how small the decision was taken still affects customer satisfaction. In this regard, tofu producers are well aware of the importance of product planning. It aims to maintain the taste of local food as typical culinary tourism of Sumedang. Sumedang Tofu is one of the factors of tourist attractions in Sumedang. In addition to infrastructure, tourist objects are also important things that must be managed (Mandić, Mrnjavac, \& Kordić, 2018). The strategy program determines the name of the program, which is about tofu cultural tourism. The program theme talks about product differentiation, which includes the socialization of media differentiation changing from conventional media banners into using digital technology in the form of websites and social media. Differentiation was also found on bamboo woven packaging which is considered to be more durable. While there was a change made toward the original chili flavor, now there are sambal kecap, sambal oncom, and sambal hejo. The type of program designed is informational with a target that all people know more about Sumedang Tofu.

\section{Communication planning that can be applied to the management of Sumedang Tofu products}

In addition to collecting initial data in the form of insight, planning in the form of a strategic program, the next step is to implement all the programs through the implementation program stages. Wilcox \& Cameron (in Wasesa, 2011) stated that this stage has a focus on communication strategies and action activities or programs. It is to specify the type of media to be used as a means of conveying the message content to consumers or the public. In the context of the results of this study, producers of Tofu Sumedang admitted that they had utilized the presence of external media for the benefit of product brandings such as websites and social media. However, the utilization of the media was not yet optimized. The use of social media is undoubtedly a beneficial branding strategy. Malthouse et al. (2013) explained that the use of social media aims at managing product branding. Digital media was born in the era of globalization through online technology in which users do not have to meet directly (Hidayat, 2014). The birth of this technology encourages a more practical and efficient work. It is time to bring tofu products as a unique culinary that is known nationally to be further recognized by the world. Social media can also be used as a strategy to manage relationships with consumers or Customer Relationships in Social Media (CRM). Similarly, the producers of Sumedang Tofu and consumers need a special media that can be used as a means to perform perceptual audits, namely to capture consumer opinions on the existence of Sumedang Tofu. The existence of mutual relationships through social media is expected to build relationships between producers and consumers. This relationship reflects the existence of consumer trust resulting in a positive assessment or positive image and reputation of Sumedang Tofu products. 


\section{The implementation program, action, and reputation.}

The Sumedang Tofu brand differentiation is the result of the creativity of Sumedang society in facing global product competition. Differentiation is needed as a strategy to preserve tofu as an icon of Sumedang culinary culture. Differentiation is a strategy to maintain the product by adding or modifying the product (Karagiannis \& Pröll, 2017). Product differentiation activities have a positive impact on consumer decisions to buy simultaneously. Kotler (in Hidayat, 2012) said that differentiation is the act of designing a set of meaningful differences to differentiate a company's offer from a competitor's offer. For physical products, companies can differentiate on aspects such as superiority or specialty of the product (packaging, taste, and price), location, durability, convenience, service and so on. As for personnel or human resources, a company should be able to identify the ability of its personnel, courtesy, credibility, reliability, quick response and other services related to the service the company offers. Similarly, the producers of Sumedang Tofu are currently trying to introduce tofu as international food, but with local uniqueness.

Differentiation becomes a demand due to business competition. Hidayat (Hidayat, 2012) said that in well-known food industry with intense competition, a small company can compete with a large company by identifying its products and services. The form of differentiation efforts made by tofu manufacturers is in the form of various names of Sumedang Tofu, such as Tofu Bungkeng, Tofu Haji Ateng, Tofu Citarasa, and other names. Differentiation is also found in the taste of sambal or sauce as a tofu side dish. Sumedang Tofu can be consumed with sambal kecap, sambal hejo, and sambal oncom. There is still an original way to consume Tofu by serving it with the whole chili. To some consumers, this way is considered more accessible to feel the texture of Sumedang Tofu. Determining product differentiation should be done with consideration. If necessary it should be based on survey results or polling on consumers who are in the target market area. This precaution is required to obtain accurate results following actual market needs. Differentiation is used by producers of Sumedang Tofu as a strategy for maintaining consumer emotionally. The same thing was also expressed by Popa et al. ( 2017) who stated that the success of a brand or evolution of a brand can enhance the prestige and value of the product and to some extent meet the psychological needs of consumers.

Differentiation is expected to introduce new products and developments from Sumedang Tofu. Differentiation is believed to be the right approach to branding tofu products. Branding is a continuous effort to introduce products, brands, and the like. Branding is also intended to build public awareness that encourages a sense of attraction, wants, confidence, and community support toward tofu. Branding is an effort to attract people. Differentiation is intended to maintain the existence of the product by providing information about Sumedang Tofu's latest products. This is in line with the statement of Popa et al. (2017) who opined that branding is an activity that aims at providing information about product brands, developing brand awareness, and creating a sense of closeness with consumers. Branding can also be interpreted as an attempt to establish different association patterns to increase brand appeal and sales.

Branding of Sumedang Tofu products is always done by the Sumedang community to introduce the product. Branding means an effort to introduce the concept of established products, and branding is part of marketing activities. Kavaratzis \& Ashworth (in Noronha, Coca-stefaniak, \& Morrison, 2017) said that building a resilient brand is a long-term commitment. Unfortunately, there is a weakness in the branding process that has been done. The producers of Sumedang Tofu have not fully realized the importance of social media as one of the branding media. In the current era of globalization, social media is beneficial to introduce local products to be known all over the world. It is not only becoming a national branding, but it also becoming an international branding. The simplicity of accessing social media encourages the branding efficiency of Sumedang Tofu products.

A tofu culinary tourism became the second identity of Sumedang city. Tofu products even managed to build a city branding for Sumedang. City branding is a managerial procedure that offers a different identity; providing cities with opportunities to perform differently, positively, and indistinguishably from other competitors (Soltani, Pieters, Young, \& Sun, 2018). According to Soltani (2018), in Japan, the use of mascots for city branding is often becoming a part of the city's planning strategy. Managing city branding is part of city marketing. The part that must be managed and marketed is the identity of the city. Mohamad, Ismail, \& Bidin, (2017) called it Corporate Identity Management (CIM). A proper communication strategy is needed to manage the company's identity. Strategies include managing messages and conveying information through appropriate media. In 
introducing the identity of the city, the community of Sumedang had been building its city branding through conventional media and directly or through word of mouth. They realized that the target is not only the local community of Sumedang but also the people who come from outside the region. The consumer or public who knows Sumedang Tofu comes from all over the archipelago. From the response given by the interview participants which were taken purposively, it was recognized that consumers' knowledge about the existence of Sumedang Tofu culinary was similar to the recognition of the culinary business activities. They had the same experience of knowing Sumedang Tofu's existence from various media such as newspapers, television, online media, billboards, and banners. There was also a guess who stated that the information he got was obtained directly or through word of mouth.

Sumedang Tofu culinary popularity is also proven when a perceptual audit was conducted. In the process of collecting data from the community, when given a question about Tofu products that they know, the average community answered Sumedang Tofu. Their experience of the Tofu brand proves that Sumedang Tofu is at the top of their minds. Wasesa (2011) said that perceptual auditing is needed to know the position of the program or product in society. Rezvanpour \& Bayat (2017) mentioned that perceptual audit is also needed to measure positioning identity. It is a way of knowing the existence or level of public acceptance of products or programs that have been implemented. Perception audit results in this research put Sumedang Tofu at the highest position compared to other Tofu types, such as Tofu Lembang, Tofu Cibuntu, and others. The branding element consists of, (1) the identity of branding, (2) positioning branding, (3) image branding. The elements are found in the city branding of Sumedang as a city with the cultural identity of tofu culinary tour. Sumedang Tofu has become one of the tofu identities in Indonesia. Sumedang Tofu is also a prima donna and better known by the community than other tofu products. Sumedang Tofu is currently getting the valuation and support from consumers. This proves that Sumedang Tofu's image as the identity of Sumedang city remains firmly attached to the society. Tofu as the identity of the city is expected to support the reputation of Sumedang city. City reputation is supported by six dimensions of presence, place, people, prerequisites, and potential (Alifahmi, 2012). These were referred to when measuring the power of Sumedang identity. From the data of research results, it is known that Sumedang always manages its presence as a cultural tourism city that has an interesting location. Sumedang's reputation is also supported by a society that is cultured, friendly and which upholds the values of multiculturalism. While from the aspect of resources, Sumedang has great potential because it has potential nature and creative human resources. All of these dimensions are a prerequisite in building the reputation of Sumedang city as a city that is consistent in managing city branding or cultural city identity in a form of tofu culinary.

Sumedang Tofu management as a city branding is also assisted by digital media websites and social media as a communication strategy. Hidayat \& Anisti (2015) called the term Internet-based media as the current media. It is a media convergence between conventional media and contemporary technology-based ones. Digital media technology was born in the era of globalization through online technology without having its users to meet directly when using social media. The birth of this technology encourages more practical and efficient work. According to Malthouse et al. (2013), social media can also be used as a strategy to manage relationships with consumers or Customer Relationships in Social Media (CRM).

\section{CONCLUSION}

The management of city branding Sumedang aims at introducing and marketing the identity of Sumedang city as a cultural tourism city in the form of Tofu culinary. The management is through communication strategy by making communication planning, which includes a strategy program. The program is the differentiation of tofu products as a form of marketing strategy. The structure of differentiation efforts made by manufacturers is in the form of various names of Sumedang Tofu, such as Tofu Bungkeng, Tofu Haji Ateng, and Tofu Citarasa. Differentiation is also found in the taste of sambal as a side dish of Tofu. Sumedang Tofu can be served with sambal kecap, sambal hejo, and sambal oncom. And yet, there is still an original way to consume Tofu by serving Tofu with the whole chili. To some consumers, this way is easier to feel the texture of Sumedang Tofu.

Branding of Sumedang Tofu products is still done conventionally. Producers of tofu use internal media such as banners and billboards. While for external media, it is not scheduled because it is only 
incidental. External media is used in news coverage activities tailored to the needs of each medium. Branding is conventionally influenced by the human resources and Sumedang Tofu target market that is focused on the local community. In reality, there are also people from outside the province who deliberately come to Sumedang to taste Tofu. Without the help of social media, the name of Sumedang Tofu is well-known throughout the archipelago.

Sumedang Tofu producers have not fully realized that in the disruptive era today branding activities can be helped through online technology-based media such as social media. Branding through the Internet media can be a choice for capacity-building strategies for effective and efficient marketing activities. Thus, the popularity of Sumedang city branding will be more leveraged. For that, it needs the awareness of the producers by integrating branding strategy through Internet technologybased media. This will bring the identity of Sumedang as a cultural tourism city in the form of Tofu culinary to be known worldwide. The management of city branding can also support the reputation of Sumedang, which has already had a reputation for presence, place, people, prerequisites, and potentials.

Suggestions are proposed to the local governments to support the promotion of Sumedang Tofu products so that they can penetrate the global market. The promotion strategy that can be done is to use technology 4.0. The era of digital media-based industries demands the flow of information goes fast and is easily accessed by consumers. Therefore, the step the local government should take for the tofu producers who so far only believe in conventional promotions will be to provide them with training or workshops on digital media technology-based promotional activities.

\section{REFERENCES}

Alifahmi, H. (2012). Proceeding Strategi Communication Branding di Era Industri Kreatif. In Integrated Communication Branding Dari Personal, Corporate Branding Menuju Country Reputation. (pp. 1-21). Malang: Universitas Brawijaya.

El-Kasim, M., \& Idid, S. A. (2016). A Test of Technology Acceptance Model in the Use of Social Media among PR Practitioners in Nigeria. SEARCH, 8(2), 20-33.

Gandhy, A., \& Hairuddin, J. A. (2018). Analysis of Promotion and Product Differentiation of Jukajo on Consumer Purchase Decision. Journal Binus Business Review, 9(March), 9-18. http://doi.org/10.21512/bbr.v9i1.3901

Hardyantoro, \& Prianti. (2012). Strategi Communication Branding di Era Industri Kreatif. In Peran Website Sebagai Penjunjang City Branding Yogyakarta. (pp. 79-105). Malang: Universitas Brawijaya.

Hazliansyah. (2018, April). Sumedang Perkuat Wisata Melalui Festival Tahu 2018. . . Republika Online. Sumedang. Retrieved from http://gayahidup.republika.co.id/berita/gayahidup/travelling/18/04/09/p6wh46280-sumedang-perkuat-wisata-melalui-festival-tahu-2018

Hidayat, D. (2012). KEMASAN BASO CINTA. Jurnal Ilmu Komunikasi UIN Sunan Ampel Surabaya, 2(2), 210-221.

Hidayat, D. (2014). Media Public Relations. Jogjakarta: Graha Ilmu.

Hidayat, D., \& Anisti, A. (2015). Wartawan Media Now dalam Mengemas Berita: Perspektif Situational Theory. Jurnal ASPIKOM, 2(5), 295. http://doi.org/10.24329/aspikom.v2i5.81

Hidayat, D., \& Hafiar, H. (2019). Nilai-nilai budaya soméah pada perilaku komunikasi masyarakat Suku Sunda. Jurnal Kajian Komunikasi, 7(1), 84-96.

Hidayat, D., Kuswarno, E., \& Zubair, F. (2017). THE IPPAR Model sebagai Komponen Etnografi PR pada Kajian Public Relations Berbasis Budaya. Ilmu Komunikasi UPN Veteran Jogjakarta, 15(April), 60-72.

Hidayat, D., Kuswarno, E., Zubair, F., \& Hafiar, H. (2017). Negosiasi Citra Budaya Masyarakat Multikultural. ASPIKOM, 3(2), 157-172.

Hidayat, D., Kuswarno, E., Zubair, F., \& Hafiar, H. (2018). Public Relations Communication Behavior Through a Local-Wisdom Approach: The Findings of Public Relations Components Via Ethnography as Methodology. Malaysian Journal of Communication, 34(3), 56-72.

Hidayat, D., \& Suhartini, T. (2018). Community Empowerment dan Product Branding "SEKHUIT." Jurnal Ilmu Komunikasi Efek (JIKE), 1(2), 41-58. 
Karagiannis, G., \& Pröll, S. (2017). Markup and Product Differentiation in the German Brewing Sector.

Malthouse, E. C., Haenlein, M., Skiera, B., Wege, E., \& Zhang, M. (2013). Managing customer relationships in the social media era: Introducing the social CRM house. Journal of Interactive Marketing, 27(4), 270-280. http://doi.org/10.1016/j.intmar.2013.09.008

Mandić, A., Mrnjavac, Ž., \& Kordić, L. (2018). Tourism Infrastructure, Recreational Facilities, and Tourism Development. Tourism and Hospitality Management, 24(1), 1-22. http://doi.org/10.20867/thm.24.1.12

Mohamad, B., Ismail, A. R., \& Bidin, R. (2017). Corporate Identity Management and Employee Brand Support : Enhancing Marketisation in Higher Education Sector, 33(3), 178-195.

Murfianti. (2012). Proceeding Strategi Communication Branding di Era Industri Kreatif. In Pencitraan Solo melalui Event Karnaval sebagai upaya Destination Branding Wisata Budaya (pp. 6577). Malang: Universitas Brawijaya.

Noronha, I. De, Coca-stefaniak, J. A., \& Morrison, A. M. (2017). place management professionals. Cities, 66(April), 91-98. http://doi.org/10.1016/j.cities.2017.04.001

Popa, V. M., Raba, D. N., \& Dumbravă, D. G. (2017). Theoretical aspects of food differentiation , brand management and rebranding. Journal of Agroalimentary Processes and Technologies, 23(2), 74-77.

Rezvanpour, N., \& Bayat, A. (2017). Determining effective urban design within the branding strategy due to brand city spaces and evaluating city spaces by Assessing the feasibility of using the heat demand-outdoor comparing them to the presented factors. A case study of temperature function fo. Energy Procedia, 115, 6-17. http://doi.org/10.1016/j.egypro.2017.05.002

Sholikhah, F. S. (2016). Strategi Media Relations PT. Telekomunikasi Indonesia, Tbk Untuk Meningkatkan Citra Perusahaan. Jurnal Komunikator, 8(284), 93-111.

Soltani, A., Pieters, J., Young, J., \& Sun, Z. (2018). Exploring city branding strategies and their impacts on local tourism success, the case study of Kumamoto Prefecture, Japan. Asia Pacific Journal of Tourism Research, $0(0), \quad 1-12$. http://doi.org/10.1080/10941665.2017.1410195

Wasesa, S. A. (2011). Political Branding \& Public Relations. Jakarta: Gramedia.

Zenker, S., Braun, E., \& Petersen, S. (2017). Branding the destination versus the place: The effects of brand complexity and identification for residents and visitors. Tourism Management, 58, 1527. http://doi.org/10.1016/j.tourman.2016.10.008 